\title{
Selectivity of cyclo-oxygenase inhibitors in human pulmonary epithelial and smooth muscle cells
}

\author{
S.P. Range, L. Pang, E. Holland, A.J. Knox
}

\begin{abstract}
Selectivity of cyclo-oxygenase inhibitors in human pulmonary epithelial and smooth muscle cells. S.P. Range, L. Pang, E. Holland, A.J. Knox. C) ERS Journals Ltd 2000.

ABSTRACT: Cyclo-oxygenase (COX) inhibitors may have a role in reducing inflammation in asthma and other pulmonary diseases. COX inhibitors have different selectivities for the two COX isoenzymes (COX 1 and COX 2) which vary between purified enzyme and intact cell preparations. The relative selectivity of $\mathrm{COX}$ inhibitors has not been studied in human airway cells.

A number of COX inhibitors in cultured human airway cells were compared which exclusively express either COX 1 (primary degree cultured human airway smooth muscle (HASM) cells) or COX 2 (A549 pulmonary epithelial cell-line) as measured by Western blotting. COX activity was assayed by prostaglandin $(\mathrm{PG}) \mathrm{E}_{2}$ production following $30 \mathrm{~min}$ incubation with $5 \mathrm{mM}$ arachidonic acid.

COX activity in both cell types was similar; HASM cells $92.2 \pm 12.1 \mathrm{ng}^{P_{G E}} \cdot \mathrm{mg}^{-1}$ protein, A549 cells $87.7 \pm 24.4 \mathrm{ng} \mathrm{PGE}_{2} \cdot \mathrm{mg}^{-1}$ protein. In HASM cells the median inhibitory concentration (IC50) was $>10^{-5} \mathrm{M}$ for nimesulide, $3.2 \times 10^{-6} \mathrm{M}$ for $\mathrm{N}$-(2-cyclohexyloxy-4-nitrophenyl)-methanesulphonamide (NS398), $1.8 \times 10^{-8} \mathrm{M}$ for flurbiprofen, $6.7 \times 10^{-9} \mathrm{M}$ for indomethacin and $>10^{-5} \mathrm{M}$ for aspirin. In A549 cells the IC50 was $1.8 \times$ $10^{-9} \mathrm{M}$ for nimesulide, 4.1 $\times \mathbf{1 0}^{-9} \mathrm{M}$ for NS398, 6.2 $\times 10^{-10} \mathrm{M}$ for flurbiprofen, $1.3 \times 10^{-8} \mathrm{M}$ for indomethacin and $>10^{-5}$ M for aspirin. Sodium valerate had no effect in either HASM or A549 cells. The COX 2: COX 1 selectivity ratio (COX 2 IC50/COX 1 IC50) was $<0.0001$ for nimesulide, 0.001 for NS398, 0.03 for flurbiprofen and 1.9 for indomethacin.

In conclusion the present study has shown that cyclo-oxygenase inhibitors have a range of selectivities for cyclo-oxygenase 1 and cyclo-oxygenase 2 in intact human airway cells. The relative cyclo-oxygenase 2 selectivity of $\mathrm{N}$-(2-cyclohexyloxy-4-nitrophenyl)-methanesulphonamide and nimesulide may have implications for the treatment of asthma and other inflammatory pulmonary diseases.

Eur Respir J 2000; 15: 751-756.
\end{abstract}

Respiratory Medicine Unit, City Hospital, Hucknall Road, Nottingham, NG5 1PB, UK

Correspondence: S.P. Range

Dept of Respiratory Medicine

University Hospital

Queen's Medical Centre

Nottingham NG7 2UH

UK

Fax: 441159424554

Keywords: A549 cells

airway smooth muscle

asthma

cyclo-oxygenase

cyclo-oxygenase inhibitor

prostaglandin $\mathrm{E}_{2}$

\section{Received: January 111999}

Accepted after revision January 232000

L. Pang was supported by the National Asthma Campaign (UK).
Recent studies have suggested that cyclo-oxygenase (COX) products may be involved in the pathophysiology of several pulmonary diseases: COX products have been implicated in the inflammation found in asthmatic airways, with different COX products exerting differential effects in different situations in vivo [1-3]. Inhaled indomethacin and aspirin protect against indirect bronchoconstrictor challenges in asthma [4, 5] suggesting that release of constrictor prostaglandins such as prostaglandin $(\mathrm{PG}) \mathrm{D}_{2}$ and $\mathrm{PGF}_{2 \alpha}$ may contribute to the mechanisms of action of these stimuli. Under different circumstances COX products may have a protective role. $\mathrm{PGE}_{2}$ has been shown to have a potential bronchoprotective role both in vitro [6,7] and in vivo $[8,9]$. Studies showing that oral indomethacin inhibits refractoriness to repeated bronchoconstriction challenge suggest that endogenous $\mathrm{PGE}_{2}$ may be involved in this protective response $[10,11]$. A small number of patients with asthma exhibit aspirin sensitivity, whereby oral aspirin and other COX inhibitors produce bronchochoconstriction. This bronchoconstriction can be prevented by inhalation of $\mathrm{PGE}_{2}[12,13]$. Collectively these studies implicate COX products in several aspects of asthma pathophysiology, but it is clear that the responses to COX inhibition depend on the inhibitor studied, the route of administration, the circumstances of use and the type of patients studied. Studies in cultured airway smooth muscle cells in vitro have suggested that COX products can also regulate adenylate cyclase function and the production of the chemokine interleukin (IL)-8 [14-16].

COX products have also been implicated in other pulmonary diseases: lung fibroblasts from patients with idiopathic pulmonary fibrosis have been shown to have a diminished capacity to synthesize $\mathrm{PGE}_{2}$ [17]. Tracheal epithelial cells containing the DF508 cystic fibrosis (CF) mutation exhibit enhanced PG synthesis compared to wild type cells [18]. Further evidence that pro-inflammatory COX products may be involved in the pathophysiology of $\mathrm{CF}$ has been provided by a study showing that the COX inhibitor ibuprofen can slow the rate of pulmonary function decline in these patients [19]. In order to gain greater insight in to the possible role of COX inhibitors in the modification of these and other pulmonary disease processes, further knowledge of the selectivity of COX inhibitors against $\mathrm{COX}$ isoforms in airway cells is required.

COX exists in two isoforms COX 1 and COX 2. COX 1 is constitutively expressed in many tissues [20], whereas COX 2 is an inducible form which has been shown to be induced in airway cells by stimuli present in inflammatory pulmonary diseases [21-23]. Airway cells from patients with asthma have been shown to express COX 2 in greater quantities than those from nonasthmatic subjects [24]. COX inhibitors are available with a range of selectivities 
for COX 1 and COX 2. The selectivity of these agents varies, however, between purified enzyme, broken cell and intact cell preparations [25]. A greater understanding of the effects of these agents in the lung requires study of their selectivity in whole cell preparations of airway cells.

COX isoforms are expressed in several airway cells. The authors and others have previously shown that COX 1 is the sole isoform expressed under resting conditions in human airway smooth muscle (HASM), and that COX 2 can be induced by cytokines, particularly IL- $1 \beta[22,26$, 27]. In contrast the epithelial cell line A549 expresses only COX 2 both under resting [28] and cytokine-stimulated conditions $[21,28]$. Similar findings have been shown in primary cultures of airway epithelial cells [21, 28, 29].

Unstimulated HASM and A549 cells therefore represent good whole cell models for studies of COX 1 and COX 2 respectively. Therefore, the effects of a number of COX inhibitors were studied in these airway cells. The COX 1 selectivity of the drugs in unstimulated HASM cells that constitutively express COX 1 was examined along with the COX 2 selectivity in unstimulated A549 epithelial cells that constitutively express COX 2 .

\section{Materials and methods}

\section{Cell culture}

Human airway smooth muscle cells. Primary cultures of adult HASM cells were prepared from explants of airway smooth muscle according to methods previously reported $[22,23,30]$. Briefly, human trachea was obtained from two post mortem individuals (one male aged $44 \mathrm{yrs}$ and one female aged 52 yrs, with no evidence of airway disease) within $12 \mathrm{~h}$ of death. The trachealis muscle was then dissected free of epithelium and connective tissue under sterile conditions. Small $(2 \times 2 \mathrm{~mm})$ explants of airway smooth muscle were then excised and $\sim 10$ explants placed in one small petri dish. The explants were incubated in $10 \%$ foetal calf serum (FCS)-Dulbecco's modified Eagle's medium (DMEM) in humidified $5 \% \mathrm{CO}_{2} / 95 \%$ air at $37^{\circ} \mathrm{C}$ and the medium was changed every 3 days. Smooth muscle cells were usually seen $\sim 7$ days later. Once confluent, cells were trypsinized and plated into $175 \mathrm{~cm}^{2}$ tissue culture flasks, grown to confluence again, trypsinized and cryopreserved at $1 \times 10^{6}$ cells $\cdot \mathrm{mL}^{-1}$. HASM cells out of cryopreservation were plated at a density of $2 \times 10^{4}$ cells $\cdot$ well $^{-1}$ in 12 -well culture plates, cultured to confluence in $10 \%$ FCS-DMEM and growth-arrested in FCS-free DMEM for $24 \mathrm{~h}$ before experiments. Cells at passage 3 were used for all experiments. The authors have previously shown that cells grown in this manner show the immunohistochemical and light microscopic characteristics of pure HASM cells [22].

A549 cells. A549 cells were purchased from the European Collection of Animal Cell Cultures (ECAAC No: 86012804; Salisbury, Wiltshire, UK). Aliquots of cells frozen in $10 \%$ dimethyl sulphoxide (DMSO) - 90\% FCS were thawed and suspended in culture medium comprising 90\% DMEM - 10\% FCS containing $2 \mathrm{mM}$ L-glutamine, $100 \mu \mathrm{g} \cdot \mathrm{mL}^{-1}$ penicillin $\mathrm{G}, 100 \mu \mathrm{g} \cdot \mathrm{mL}^{-1}$ streptomycin and $2.5 \mu \mathrm{g} \cdot \mathrm{mL}^{-1}$ amphotericin B. The DMSO was removed by centrifugation at $100 \times g$. Cells were resuspended in the above culture medium and plated in 12-well cultured plates at a seeding density of $1 \times 10^{4}$ cells $\cdot \mathrm{cm}^{-2}$ and grown in $95 \%$ air $/ 5 \% \mathrm{CO}_{2}$ at $37^{\circ} \mathrm{C}$. Culture media was replaced on alternate days until the cells were confluent. Cells were growth arrested for $24 \mathrm{~h}$ in media without FCS prior to all experiments.

\section{Cyclo-oxygenase activity}

Prior to each experiment, the culture medium was replaced with fresh culture medium without FCS. The COX inhibitor to be studied dissolved in DMSO (final concentration $1 \%$ volume/volume) or DMSO control was then added, and the cells were incubated at $37^{\circ} \mathrm{C}$ for $15 \mathrm{~min}$. Exogenous arachidonic acid (AA; final concentration 5 $\mu \mathrm{M}$ ) was then added and the cells were incubated for a further $30 \mathrm{~min}$ at $37^{\circ} \mathrm{C}$. Media was removed and immediately frozen and stored at $-20^{\circ} \mathrm{C}$ until assayed for $\mathrm{PGE}_{2}$. Six COX inhibitors were studied based on their selectivity in other systems: valeryl salicylate, a COX 1 selective inhibitor; nimesulide and N-(2-cyclohexyloxy-4-nitrophenyl)methanesulphonamide (NS 398), both COX 2 selective; and the nonselective COX inhibitors aspirin, indomethacin, and flurbiprofen.

\section{Prostaglandin $E_{2}$ assay}

$\mathrm{PGE}_{2}$ concentration was determined by radioimmunoassay as previously described [31]. The authors have previously validated this assay $[22,23,31]$ and have shown it to have a low cross-reactivity with other metabolites of AA $[22,23]$. Each sample analysed for $\mathrm{PGE}_{2}$ was assayed in duplicate.

\section{Protein assay}

Cell protein was assayed in cell cultures used for Western blot analysis and relative COX activity. Following removal of the cell media for $\mathrm{PGE}_{2}$ estimation, extractable protein was removed from the cells by incubation with an extraction buffer $(0.9 \% \mathrm{NaCl}, 20 \mathrm{mM}$ tris- $\mathrm{HCl}, \mathrm{pH} 7.6$, $0.1 \%$ triton $\times 100,1 \mathrm{mM}$ phenylmethylsulforyl fluoride, $0.01 \%$ leupeptin) with gentle shaking. Extracted protein concentration was determined using the Bio-Rad protein assay (Bio-Rad Laboratories Ltd, Hemel Hempstead, Hertfordshire, UK).

\section{Western blot analysis of cyclo-oxygenase isoenzymes}

Thirty micrograms of extracted protein was mixed 1:1 with sample buffer $(20 \mathrm{mM}$ tris-HCl, $\mathrm{pH} 6.8,20 \%$ glycerol, $2 \%$ sodium dodecylsulphate (SDS), 5\% 2-mercaptoethanol and $0.025 \%$ bromophenol blue) and boiled for 5 min prior to electrophoresis in $20 \times 20 \mathrm{~cm} 7.5 \%$ SDSpolyacrylamide gel $(45 \mathrm{~mA}, 5 \mathrm{~h})$. Separated proteins were electroblotted $(150 \mathrm{~V}, 3 \mathrm{~h})$ to pure nitrocellulose membranes (Gelman Sciences, Northampton, Northamptonshire, UK) and the blot was blocked for $2 \mathrm{~h}$ at $4{ }^{\circ} \mathrm{C}$ in blocking reagent $(8 \%$ fat-free dried milk powder in phosphatebuffered saline (PBS) pH 7.4 with $0.3 \%$ Tween-20 (PBS$\mathrm{T})$ ). The blot was then incubated with primary monoclonal anti-human COX 2 antibody (Cayman Chemical, Ann Arbor, MI, USA, 1:2,000 in blocking reagent) for $2 \mathrm{~h}$ at room temperature. The blot was subsequently washed with PBS-T and incubated with polyclonal anti-mouse immunoglobulin (Ig) $G$ coupled with horseradish peroxidase 
(1:2000 in blocking re-agent) for $1 \mathrm{~h}$ at room temperature. Semiquantitative staining was achieved by using enhanced chemiluminescence (ECL) detection. The blot was washed with PBS-T and then incubated with SuperSignal ${ }^{\mathrm{TM}}$ chemiluminescence (CL)-HRP Substrate System (Pierce, Rockford, IL, USA); for $1 \mathrm{~min}$ and finally exposed to Hyperfilm-ECL (Amersham Life Science, Little Chalfont, Buckinghamshire, UK). Reprobing of COX 1 was carried out by incubating the membrane in stripping buffer (100 $\mathrm{mM}$ 2-mercaptoethanol, 2\% SDS, $62.5 \mathrm{mM}$ Tris- $\mathrm{HCl}$ ) at $50^{\circ} \mathrm{C}$ for $30 \mathrm{~min}$ with occasional agitation, washing the membrane in large volumes of PBS-T, blocking the membrane for $2 \mathrm{~h}$ in blocking reagent at $4^{\circ} \mathrm{C}$ and then following the above steps to detect COX 1 with monoclonal antiovine COX 1 antibody with cross-reactivity to human COX 1 (Cayman Chemical, Ann Arbor, MI, USA, 1:2,000 in blocking reagent).

\section{Materials}

Hyperfilm-ECL and $\left(5,6,8,11,12,14,15(\mathrm{n})-{ }^{3} \mathrm{H}\right)-\mathrm{PGE}_{2}$ (6.737 TBQ $\mathrm{mmol}^{-1}$ ) were purchased from Amersham Life Science. Pure nitrocellulose blotting membrane was obtained from Gelman Sciences. SuperSignal CL-HRP Substrate System was obtained from Pierce. Polyclonal anti-mouse IgG coupled with horseradish peroxidase was obtained from Transduction Laboratories (Lexington, KY, USA). NS398, nimesulide, valeryl salicylate, monoclonal anti-human COX 2 antibody and monoclonal anti-ovine COX 1 antibody (with cross-reactivity to human COX 1) were obtained from Cayman Chemical. FCS was obtained from Seralab Ltd (Crawley Down, Sussex, UK). All cell culture plastics were obtained from Costar (Cambridge, MA, USA). All other chemicals and reagents were obtained from Sigma.

\section{Analysis}

Data for each experimental condition represents the mean \pm SEM of 3-4 separate experiments performed on different experimental days. Each experiment consisted of 2-4 replicates for each concentration of COX inhibitor studied. The results show absolute $\mathrm{PGE}_{2}$ production or \% $\mathrm{PGE}_{2}$ produced relative to control cells not pre-incubated with COX inhibitor. Median effective concentration (EC50) values and their 95\% confidence intervals were calculated

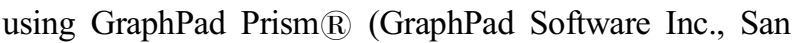
Diego, CA, USA) using nonlinear regression.

\section{Results}

\section{Cyclo-oxygenase expression}

COX isoenzyme expression in the two cell types under unstimulated conditions is shown in figure 1. Under growth arrested conditions HASM cells exclusively expressed COX 1, whilst A549 cells exclusively expressed COX 2.

\section{Cyclo-oxygenase activity}

The relative COX activity per unit of extractable protein of the two cell types was measured under growth arrested conditions. The results represent the mean \pm SEM of six experiments consisting of at least three replicates performed on separate days. $\mathrm{PGE}_{2}$ production $(5 \mu \mathrm{M} \mathrm{AA}, 30 \mathrm{~min}$,

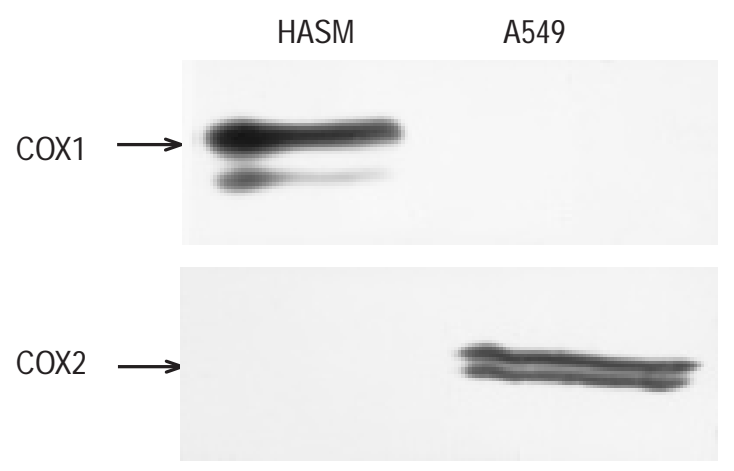

Fig. 1. - Western blot analysis of cyclo-oxygenase (COX) isoenzyme expression (bands at $70 \mathrm{kDa}$ ) in human airway smooth muscle (HASM) and pulmonary epithelial cell-line A549 cells under unstimulated conditions. Data represents a single experiment which was representative of others carried out on different days $(n=3)$.

$37^{\circ} \mathrm{C}$ ) by HASM cells was $92 \pm 12 \mathrm{ng} \cdot \mathrm{mg}^{-1}$ protein, and $87 \pm 24 \mathrm{ng} \cdot \mathrm{mg}^{-1}$ protein by A549 cells.

\section{Cyclo-oxygenase inhibition}

COX activity was measured in both cell types following preincubation with selective and nonselective COX inhibitors at concentrations of $10^{-11}-10^{-5} \mathrm{M}$ (fig. 2). COX activity median inhibitory concentration (IC50) values together with COX 2:COX 1 selectivity ratios for the COX inhibitors studied are shown in table 1 . The COX activity of HASM cells could not be inhibited to $50 \%$ of baseline by $10^{-5} \mathrm{M}$ aspirin or $10^{-5} \mathrm{M}$ nimesulide, precluding accurate calculation of the IC50 value. Aspirin $10^{-5} \mathrm{M}$ also failed to inhibit COX activity in A549 cells by $50 \%$. Preincubation of both HASM and A549 cells with valeryl salicylate $\left(10^{-11}-10^{-5} \mathrm{M}\right)$ did not significantly inhibit COX activity (data not shown).

\section{Discussion}

COX inhibitors may have a clinical role in the treatment of a number of pulmonary inflammatory diseases. The current results show that HASM and A549 cells are good intact cell models for the study of the selectivity of COX inhibitors in pulmonary tissues in vitro. Under unstimulated conditions HASM and A549 cells exclusively express the COX 1 and COX 2 protein, respectively. Western blotting was used to detect COX 1 and COX 2 protein. The authors feel confident that these results are an accurate reflection of the isoenzyme expression in these cells under unstimulated conditions and have previously shown that these antibodies are isoenzyme specific $[22,23]$. Similar findings using Western blotting have previously been reported by the current authors and others $[22,23,26-$ 28]. Also previous studies using Northern blotting have confirmed the exclusive presence of COX 1 messenger ribonucleic acid (mRNA) in HASM cells [28, 29].

Direct comparisons between the absolute level of COX activity found in the current cells and previous work is difficult due to differences in methodology and the units of expression used. The only other study to compare COX activity in unstimulated HASM and A549 cells using similar methodology compared COX activity expressed per $10^{5}$ cells [28], and found a similar level of COX activity in A549 cells but a $>30$-fold greater level of COX activity in 

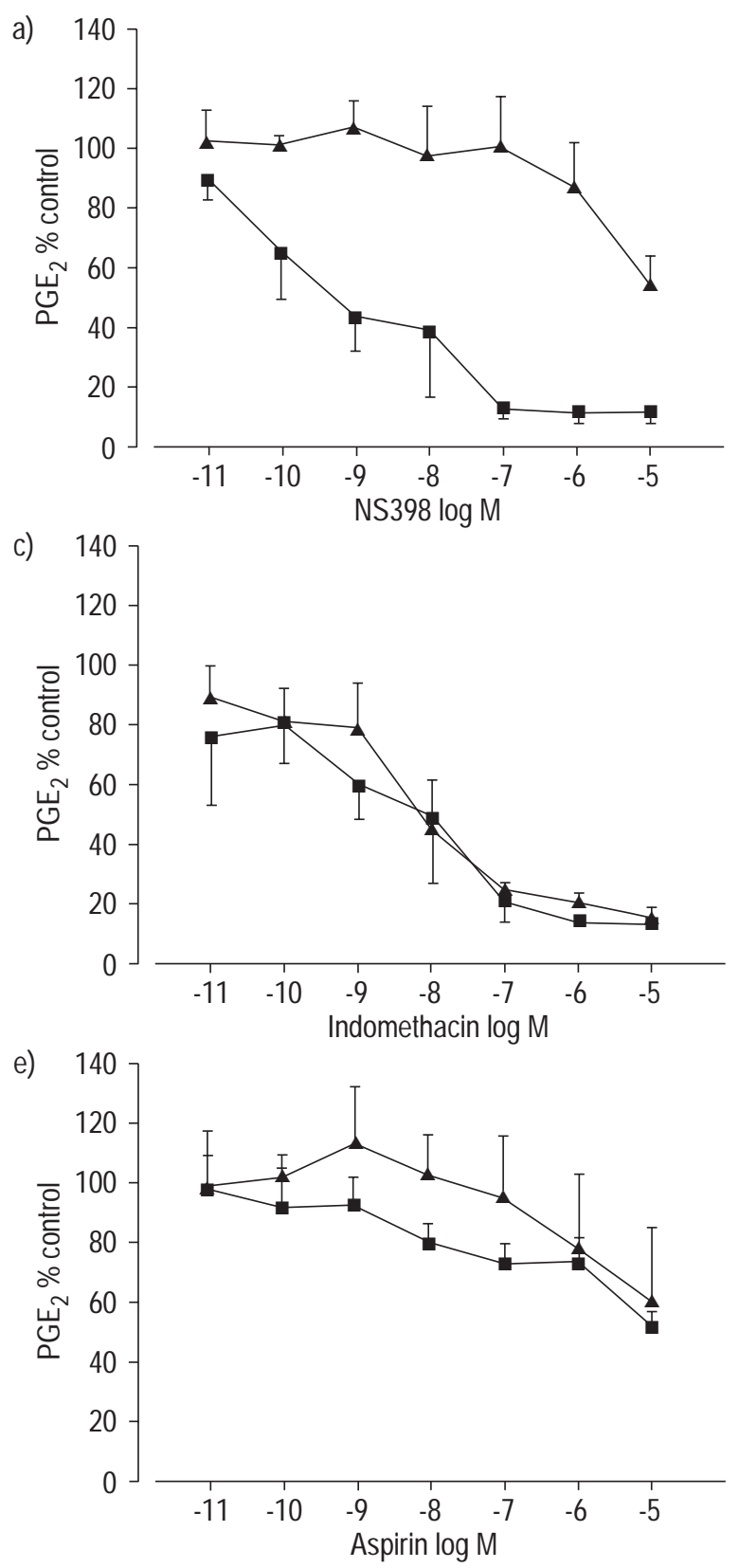

HASM cells. This may reflect differences present in the cell culture techniques used, or it may be due to the different site of origin of the HASM cells (cells used in the present study were primary cultures of tracheal smooth muscle cells, whereas those used by AsANo et al. [28] were a commercially available cell line of human bronchial smooth muscle cells).

In order to develop selective COX inhibitors for use in pulmonary disease it is desirable to have data on their selectivity in whole airway cells. The use of whole cells is especially important as marked differences in selectivity exist between purified enzyme and whole cell preparations [25]. Although many studies in airway cells have used COX inhibitors to probe the role of COX products in different experimental situations, the COX selectivity of these agents in airway cells has not been formally compared.

None of the COX inhibitors that were examined in the present study demonstrated COX 1 selectivity. Preincuba- b)

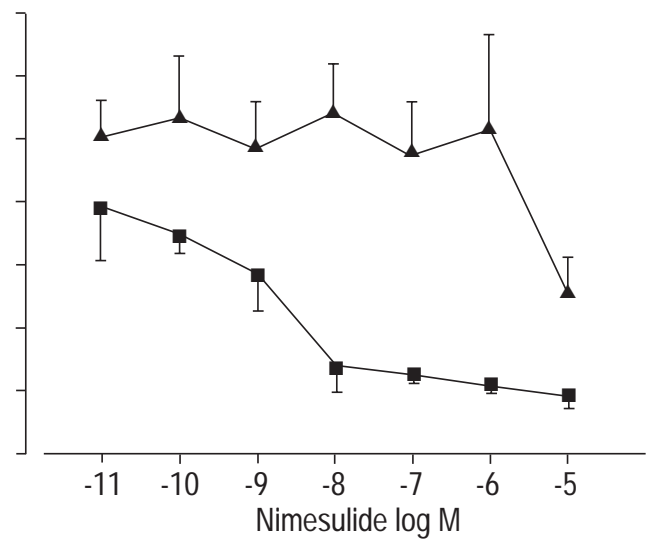

d)

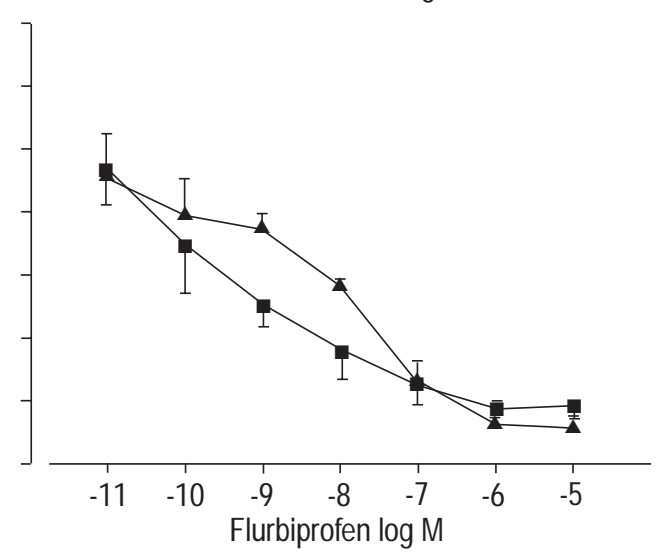

Fig. 2. - Inhibition of cyclo-oxygenase activity $(5 \mu \mathrm{M}$ arachidonic acid, $30 \mathrm{~min}, 37^{\circ} \mathrm{C}$ ) assayed by prostaglandin $(\mathrm{PG}) \mathrm{E}_{2}$ production in human airway smooth muscle cells $(\boldsymbol{\Delta})$ and pulmonary epithelial cellline A549 cells ( $\boldsymbol{\square}$ ) by: a) N-(2-cyclohexylosy-4-mitrophenyl)-methanesulphonamide (NS398); b) nimesulide; c) indomethacin; d) flurbiprofen; and e) aspirin. Data represents the mean \pm SEM of at least three separate experiments.

tion of both cell types with valeryl salicylate, a selective COX 1 inhibitor failed to produce significant COX inhibition. The authors believe this is most likely to be due to poor cellular uptake of this drug over the time course of the experiments. Although valeryl salicylate has been shown to inhibit COX 1 selectively in murine mast cells [32] extensive experimental data on this compound is lacking. Aspirin was the least potent of the other COX inhibitors studied. Aspirin $10^{-5} \mathrm{M}$ did not produce a $50 \%$ inhibition of COX activity in either A549 or HASM cells (between $40 \%$ and $50 \%$ inhibition achieved for both cell types). This lack of potency compared with other COX inhibitors has been previously observed in other intact cell preparations $[25,33]$. The level of COX 2 inhibition caused by aspirin in the present experiments was similar to that found in previous intact cell preparations, but the level of COX 1 inhibition was $\sim 10$-fold less than that previously reported [25, 33]. 
Table 1. - Median inhibitory concentration (IC50) values of cyclo-oxygenase (COX) inhibitors for inhibition of prostaglandin $\mathrm{E}_{2}$ production by human airway smooth muscle cells (COX 1 IC50) and pulmonary epithelial cell-line A549 cells (COX 2 IC50)

\begin{tabular}{lccc}
\hline $\begin{array}{l}\text { COX } \\
\text { inhibitor }\end{array}$ & COX 1 IC50 & COX 2 IC50 & $\begin{array}{c}\text { COX2: } \\
\text { COX1 ratio }\end{array}$ \\
\hline Aspirin & $>10^{-5} \mathrm{M}$ & $>10^{-5} \mathrm{M}$ & - \\
Indomethacin & $6.7 \times 10^{-9} \mathrm{M}$ & $1.3 \times 10^{-8} \mathrm{M}$ & 1.9 \\
& $\left(1.7 \times 10^{-9}-\right.$ & $\left(1.7 \times 10^{-9}-\right.$ & \\
& $\left.2.6 \times 10^{-8}\right)$ & $\left.9.7 \times 10^{-8}\right)$ & \\
Flurbiprofen & $1.8 \times 10^{-8} \mathrm{M}$ & $6.2 \times 10^{-10} \mathrm{M}$ & 0.03 \\
& $\left(6.4 \times 10^{-9}-\right.$ & $\left(1.5 \times 10^{-10}-\right.$ & \\
& $\left.4.8 \times 10^{-8}\right)$ & $\left.2.5 \times 10^{-9}\right)$ & \\
Nimesulide & $>10^{-5} \mathrm{M}$ & $1.8 \times 10^{-9} \mathrm{M}$ & $<0.0001$ \\
& & $\left(4.3 \times 10^{-10}-\right.$ & \\
& & $\left.7.2 \times 10^{-9}\right)$ & \\
NS 398 & $3.2 \times 10^{-6} \mathrm{M}$ & $4.1 \times 10^{-9} \mathrm{M}$ & 0.001 \\
& $\left(1.2 \times 10^{-7}-\right.$ & $\left(5.4 \times 10^{-10}-\right.$ & \\
& $\left.8.1 \times 10^{-5}\right)$ & $\left.3.1 \times 10^{-8}\right)$ & \\
\hline
\end{tabular}

Data is shown as the mean, with $95 \%$ confidence limits in parentheses, of at least three different experiments.

In the current experiments indomethacin did not exhibit the relative COX 1 selectivity that has been demonstrated in some [25, 34], but not all nonpulmonary cell types [33]. The COX 1 IC50 for indomethacin in HASM cells in the current study was found to be similar to that previously reported in bovine aortic endothelial cells [25]. The COX 2 IC50 for indomethacin in the current experiments was also similar to that previously reported in hamster ovary cells [33]. The COX 1 IC50 for flurbiprofen in the current experiments was similar to that previously reported in microsomal preparations from cos- 1 cells transfected with murine COX 1 [34]. The COX 2 IC50 for flurbiprofen was considerably less than that previously reported [34], which was reflected in a low $\mathrm{COX} 2 / \mathrm{COX} 1$ ratio, indicating relative COX 2 selectivity. It is suspected that this discrepancy may at least in part be explained by the comparison of intact cells and sub-cellular preparations. In contrast to the other COX inhibitors studied, both nimesulide and NS398 exhibited marked selectivity for the COX 2 isoenzyme (COX 2: COX 1 IC50 ratio $\leq 0.001)$. This suggests that the COX 2 selectivity of these agents previously demonstrated in purified enzyme preparations $[35,36]$ is preserved in whole airway cells.

None of the drugs tested in the present cells were COX 1 selective and therefore are unlikely to be useful in probing the role of COX 1 in inflammatory lung disease. The pronounced COX 2 selectivity of nimesulide and NS398 makes both these drugs good candidates for selective isoenzyme inhibition in the lung and for probing the role of COX 2 in inflammatory lung diseases. The current authors and others have previously shown that different pulmonary cells express COX 2 (either de novo or in increased quantities) when stimulated with inflammatory cytokines $[21,22,26,27]$. These inflammatory cytokines have been shown to be present in increased quantities in bronchoalveolar lavage samples from patients with inflammatory lung diseases such as asthma $[37,38]$. If COX 2 is induced in inflammatory lung disease it may therefore be possible to use COX 2 selective inhibitors to selectively reduce the secretion of pro-inflammatory prostanoids, such as $\mathrm{PGD}_{2}$ and $\mathrm{PGF}_{2} \mathrm{a}$, without inhibiting the secretion of "housekeeping" prostanoids generated by COX 1 .

Do the relative potencies of the COX inhibitors in airway cells help resolve some of the inconsistent or conflicting effects of these agents in asthma? The equal or greater affinity for the COX 1 isoenzyme by many COX inhibitors including aspirin and indomethacin may lead to preferential inhibition of "housekeeping" prostaglandin production (COX 1). This might explain why aspirin may trigger asthma in a small minority of patients with "aspirinsensitive" asthma. The finding that nimesulide (shown to be COX 2 specific in the current study) does not cause bronchoconstriction in aspirin-sensitive asthmatics [39] would be consistent with this. This group of patients are not representative of the majority of asthmatics however.

When given in high doses by inhalation to patients who do not have "aspirin sensitive" asthma, both aspirin and indomethacin have been shown to have protective effects against induced bronchoconstriction $[4,5,40]$. If this was a COX 1 effect, it would be unlikely to require such high concentrations given locally. This would suggest that it is mediated by COX 2 inhibition, and that the products of COX 2 are contributing to airway inflammation in the majority of asthmatics. Interestingly flurbiprofen demonstrated selectivity towards COX 2 in the present study and was the most potent of the three inhibitors in current use clinically: studies with flurbiprofen in asthma have shown that unlike aspirin and indomethacin it has a protective effect when given by the oral route [41].

In conclusion, it has been shown that cyclo-oxygenase inhibitors exhibit a spectrum of selectivity in intact pulmomonary models of cyclo-oxygenase 1 and cyclo-oxygenase 2 expression. Drugs such as N-(2-cyclohexyloxy-4nitrophenyl)-methanesulphaonamide and nimesulide may prove useful in probing the role of cyclo-oxygenase 2 in asthma and other inflammatory lung diseases.

Acknowledgements. The authors thank R. Tuck for secretarial assistance.

\section{References}

1. Iwamoto I, Umibe T, Nakajima H, Yoshida S. Effect of a selective thromboxane $\mathrm{A}_{2}$ receptor antagonist Bay-U3405 on antigen-induced, leukotriene $\mathrm{C}_{4}$ - induced and leukotriene $\mathrm{D}_{4}$ - induced bronchoconstriction in guinea-pigs. Int Arch Allergy Immunol 1995; 108: 68-73.

2. Johnston SL, Freezer NJ, Ritter W, Otoole S, Howarth $\mathrm{PH}$. Prostaglandin $\mathrm{D}_{2}$-induced bronchoconstriction is mediated only in part by the thromboxane prostanoid receptor. Eur Respir J 1995; 8: 411-415.

3. Pavord ID, Tattersfield AE. Bronchoprotective role for endogenous prostaglandin $\mathrm{E}_{2}$. Lancet 1995; 345: 436-438.

4. Bianco S, Vaghi A, Pieroni MG, Robuschi M, Refini RM, Sestini P. Protective activity of inhaled non-steroidal antiinflammatory drugs on bronchial responsiveness to ultrasonically nebulised water. J Allergy Clin Immunol 1992; 90: 833-839.

5. Polosa R, Milazzo VL, Magri S, et al. Activity of inhaled lysine acetylsalicylate (L-ASA) on bradykinin-induced bronchoconstriction in asthmatics: evidence of contribution of prostaglandins. Eur Respir J 1997; 10: 866-871.

6. Ito I, Suzuki H, Aizawa H, Hirose T, Hakoda H. Prejunctional inhibitory action of prostaglandin $\mathrm{E}_{2}$ on excitory neuro-effector transmission in the human bronchus. Prostaglandins 1990; 39: 639-655. 
7. Peters SP, Schulman ES, Schleimer RP, Macglashan DW, Newball HH, Lichtenstein LM. Dispersed human lung mast cells. Pharmacologic aspects and comparison with human lung fragments. Am Rev Respir Dis 1982; 126: 1034-1039.

8. Pavord ID, Wisniewski A, Mathur R, Wahedna I, Knox AJ, Tattersfield AE. Effect of inhaled prostaglandin $E_{2}$ on bronchial reactivity to sodium metabisulphite and methacholine in patients with asthma. Thorax 1991; 46: 633-637.

9. Melillo E, Woolley KL, Manning PJ, Watson RM, $\mathrm{O}^{\prime}$ Byrne PM. Effect of inhaled $\mathrm{PGE}_{2}$ on exercise-induced bronchoconstriction in asthmatic subjects. Am J Respir Crit Care Med 1994; 149: 1138-1141.

10. Mattoli S, Foresi A, Corbo GM, Valente S, Ciappi G. The effect of indomethacin on the refractory period occurring after the inhalation of ultrasonically nebulised distilled water. J Allergy Clin Immunol 1987; 79: 678-683.

11. O'Byrne PM, Jones GL. The effect of indomethacin on exercise-induced bronchoconstriction and refractoriness after exercise. Am Rev Respir Dis 1986; 134: 69-72.

12. Sestini P, Armetti L, Gambaro G, et al. Inhaled $\mathrm{PGE}_{2}$ prevents aspirin-induced bronchoconstriction and urinary LTE4 excretion in aspirin-sensitive asthmatics. $\mathrm{Am} \mathrm{J}$ Respir Crit Care Med 1996; 153: 572-575.

13. Szczeklik A, Mastalerz L, Nizankowska E, Cmiel A. Protective and bronchodilator effects of prostaglandin $\mathrm{E}$ and salbutamol in aspirin induced asthma. Am J Respir Crit Care Med 1996; 153: 567-571.

14. Pang L, Holland H, Knox AJ. Role of COX 2 induction in interleukin-1 $\beta$ induced attenuation of cultured human airway smooth muscle cell cAMP generation in response to isoprenaline. Br J Pharmacol 1998; 125: 1320-1328.

15. Pang L, Holland H, Knox AJ. Impaired cAMP production in human airway smooth muscle cells by bradykinin: role of cyclooxygenase products. Am J Physiol (Lung Cell Mol Physiol) 1998; 275: L322-L329.

16. Pang L, Knox AJ. Bradykinin stimulated IL-8 production in cultured human airway smooth muscle cells: role of cyclooxygenase products. J Immunol 1998; 161: 2509-2515.

17. Wilborn J, Crofford LJ, Burdick MD, Kunkel SL, Strieter RM, Peters-Golden M. Cultured lung fibroblasts isolated from patients with idiopathic pulmonary fibrosis have diminished capacity to synthesize $\mathrm{PGE}_{2}$ and express COX 2. J Clin Invest 1995; 95: 1861-1868.

18. Levistre R, Lemnaouar M, Rybkine T, Bereziat G, Masliah J. Increase of bradykinin-stimulated arachidonic acid release in a delta F508 cystic fibrosis epithelial cell line. Biochim Biophys Acta 1993; 1181: 233-239.

19. Konstan MW, Byard PJ, Hoppel CL, Davis PB. Effect of high-dose ibuprofen in patients with cystic fibrosis. $N$ Engl J Med 1995; 332: 848-854.

20. Simmons DL, Xie W, Chipman JG, Evett GE. Multiple cyclooxygenases: cloning of a mitogen-inducible form. In: Bailey JM, ed. Prostaglandins, Leukotrienes, Lipoxins and PAF. New York, NY, USA, Plenum, 1991; pp. 67-78.

21. Mitchell JA, Belvisi MG, Akarasereenont P, et al. Induction of cyclo-oxygenase-2 in human pulmonary epithelial cells: regulation by dexamethasone. Br J Pharmacol 1994; 113: 1008-1014.

22. Pang LH, Knox AT. Effect of interleukin-1 $\beta$, tumour necrosis factor-a and interferon- $\gamma$ on the induction of cyclo-oxygenase-2 in cultured human airway smooth muscle cells. Br J Pharmacol 1997; 121: 579-587.

23. Pang LH, Knox AJ. PGE 2 release by bradykinin in human airway smooth muscle cells: involvement of cyclooxygenase-2 induction. Am J Physiol (Lung Cell Mol Biol) 1997; 273: L1132-L1140.

24. Sousa AR, Pfister R, Christie PE, et al. Enhanced ex- pression of cyclo-oxygenase isoenzyme $2(\mathrm{COX}-2)$ in asthmatic airways and its cellular distribution in aspirinsensitive asthma. Thorax 1997; 52: 940-945.

25. Mitchell JA, Akarasereenont P, Thiemermann C, Flower RJ, Vane JR. Selectivity of nonsteroidal anti-inflammatory drugs as inhibitors of constitutive and inducible cyclooxygenase. Proc Natl Acad Sci USA 1994; 90: 11693-11697.

26. Belvisi MG, Saunders MA, Haddad E-B, et al. Induction of cyclo-oxygenase- 2 by cytokines in human cultured airway smooth muscle cells: novel inflammatory role of this cell type. Br J Pharmacol 1997; 120: 910-916.

27. Vigano T, Habib A, Hernandez A, et al. Cyclooxygenase2 and synthesis of $\mathrm{PGE}_{2}$ in human bronchial smooth muscle cells. Am J Respir Crit Care Med 1997; 155: 864-868.

28. Asano K, Lilly CM, Drazen DM. Prostaglandin G/H synthase-2 is the constitutive and dominant isoform in cultured lung epithelial cells. Am J Physiol (Lung Cell Mol Physiol) 1996; 271: L126-L131.

29. Alpert SE, Walenga RW, Jaspers I, Qu Q, Chen LC. Ozone inactivates cyclooxygenase in human tracheal epithelial cells without altering PGHS-2 mRNA or protein. Am $J$ Physiol (Lung Cell Mol Physiol) 1997; 272: L879-L887.

30. Hall IP, Widdops S, Townsend P, Daykin K. Control of cyclic AMP levels in primary culture of human tracheal smooth muscle cells. Br J Pharmacol 1992; 107: 422-428.

31. Delamere F, Holland E, Patel S, Bennett J, Pavord I, Knox A. Production of $\mathrm{PGE}_{2}$ by bovine cultured airway smooth muscle cells and its inhibition by cyclo-oxygenase inhibitors. Br J Pharmacol 1994; 111: 983-988.

32. Murakami M, Bingham CO III, Matsumoto R, Austen KF, Arm JP. IgE-dependent activation of cytokine-primed mouse cultured mast cells induces a delayed phase of prostaglandin D2 generation via prostaglandin endoperoxide synthase-2. J Immunol 1995; 155: 4445-4453.

33. Chulada P, Langenbach R. Differential inhibition of Murine prostaglandin synthase- 1 and -2 by nonsteroidal anti-inflammatory drugs using exogenous and endogenous sources of arachidonic acid. J Pharmacol Exp Therapeutics 1997; 280: 606-613.

34. Meade EA, Smith WL, Dewitt DL. Differential inhibition of prostaglandin endoperoxide synthase (cyclooxygenase) isoenzymes by aspirin and other non-steroidal anti-inflammatory drugs. J Biol Chem 1993; 268: 6610-6614.

35. Curnock AP, Robson PA, Yea CM, et al. Potencies of leflunomide and HR325 as inhibitors of prostaglandin endoperoxide $\mathrm{H}$ synthase-1 and -2: comparison with nonsteroidal anti-inflammatory drugs. $J$ Pharmacol Exp Therapeutics 1997; 282: 339-347.

36. Tavares IA, Bishai PM, Bennett A. Activity of nimesulide on constitutive and inducible cyclooxygenases. Arzneimittel-Forschung 1995; 45: 1093-1095.

37. Mattoli S, Mattoso VL, Solopertro M, Allegra L, Fasoli A. Cellular and biochemical characteristics of bronchoalveolar lavage fluid in symptomatic non-allergic asthma. J Allergy Clin Immunol 1991; 87: 794-802.

38. Broide DH, Lotz M, Cuomo AG, Coburn DA, Federman EC, Wasserman SI. Cytokines in symptomatic asthma airways. J Allergy Clin Immunol 1992; 89: 958-967.

39. Bianco S, Robuschi M, Petrigni G, et al. Efficacy and tolerability of nimesulide in asthmatic patients intolerant to aspirin. Drugs 1993; 46: Suppl. 1, 115-120.

40. Crimi N, Polosa R, Magri S, et al. Inhaled lysine acetylsalicylate (L-ASA) attenuates the bronchoconstrictor response to adenosine 5'monophosphate (AMP) in asthmatic subjects. Eur Respir J 1995; 8: 905-912.

41. O'Connor BJ, Barnes PJ, Chung KF. Inhibition of sodium metabisulphite-induced bronchoconstriction by frusemide in asthma: role of cyclooxygenase products. Thorax. 1994; 49: 307-311. 